\title{
Influence of Physiographic Conditions on the Quality of Agricultural Production Area**
}

\section{Introduction}

Physiographic conditions are factors that, in the process of spatial planning, limit opportunities for agricultural production as well as residential use of land. Physiographic conditions are linked to land use preferences, including their residential or agricultural potential. Agricultural production area in its substantive and measurable aspect $[25,17,20]$ should be analyzed and evaluated in the context of the utility of its resources for agricultural needs. From the agricultural point of view, the core features of soils are quality and fitness for agricultural use. What is also important is the possibility of defining and evaluating cultivation difficulty or degree of soil erosion risk. These issues require a detailed analysis of relief configuration. Also it is necessary to confront the results of the study of land slopes with information about mechanical composition of soils. Another important element of the analyses is the land use map.

GIS tools play a crucial role in modelling spatial phenomena [6], as they make it possible to conduct a comprehensive anlysis of available spatial data [16, 22], including the modelling of erosion processes [5].

The purpose of this article is to analyze and evaluate the resources of agricultural production area in the context of soil fitness for agricultural production and potential risk of surface water erosion.

\section{Influence of Surface Water Erosion on Agricultural Production Area}

The process of surface water erosion, defined a number of times [15], although natural, brings about a set of unfavourable consequences from the point of view of agriculture [10]. Surface water erosion depends on the intensity of rainfall, soil

* University of Agriculture in Krakow, Department of Spatial Planning and Landscape Architecture, Krakow, Poland

** The results of research carried out under the theme No DS 3371/KGPIAK/2014 were financed with a grant to study provided by the Ministry of Science and Higher Education 
suscetibility to washing and above all, the type of vegetation cover $[12,13,5]$. The phenomenon of erosion, often presented at a 5-point scale of intensity [9], may be compound by intensive agriculture. That is why erosion is not only a natural problem but also an economic and social issue [10]. 20\% of land in Poland is susceptible to erosion [5]. From the environmental point of view, erosion causes destruction, thereby reducing soil profile, washing out nutrients and transporting out the eroded materials [1]. From the economic point of view, soil productivity decreases, water melioration constructions and sometimes even roads are silted. The social aspect of post-erosional consequences is related to the need to apply additional fertilization of degraded land, which leads to yield reduction [10]. The fact that erosion processes have negative impact on agricultural production area justifies the need to consider soil protection against erosion in legal provisions. The Polish Act on the protection of agricultural lands and forests [24] states that the owner of the land is responsible for adverse effects of erosion in the landscape, whilst this is directly supervised by the local head of district [24]. The problem of preventing erosion and its effects also occurs in the context of agri-environmental programmes for the development of rural areas; soil erosion is one of the risks defined by the European Commission in the so-called Strategy for Soil Protection [3, 11]. Water erosion is measured and monitored with the help of photogrammetry and remote sensing by the modelling of erosion hazards [2], which includes the measurement of slope gradients, sun exposure and length of slopes, surface area covered with grooves, vegetation cover, agriculture type as well as hydrographic and road network. The actual erosion effects are also studied with the help of experimental fields [5]. Traditional methods lean on stereographic or digital interpretation of aerial photos. They also include the interpretation of satellite photos or quantitative monitoring of erosion processes based on surface laser scanning [18]. Both the measurement and monitoring of erosion processes, which means examining the current state, and also the possibility of defining potential degrees of soil erosion by surface water are essential for the design of erosion control measures, including changes in land use, activities leading to increased landscape retention [7] and planning of the development of areas at risk of erosion in the process of spatial planning for communities. Undoubtedly, erosion processes hinder the possibilities of agricultural use of lands. On the other hand, areas threatened with erosion can in fact have potential for landscape development, for example, towards tourist or recreational functions [5].

\section{Analysis of Agrotechnical Challenges}

The decision to change the type of land use of agricultural areas should be preceded by the analysis of soil gravity for cultivation. This issue meets with lower interest of the authors than the previously described erosion phenomena. The analysis of cultivation difficulty is a study that confronts relief configuration with soil 
texture class. Specialist literature provides a 7-degree scale of cultivation difficulty $[8,14]$. The knowledge of agronomic difficulties may be crucial in taking decisions about land use changes, including removal of stones or change of soil texture class in the course of land recultivation. While erosion is associated with the occurrence of certain physiographic and climate conditions and their confrontation with the type of land use; the analysis of agronomic difficulties concerns only current cultivation within the agricultural production areaa; thus it solely refers to the agricultural use of arable lands. According to specialist literature [14], difficulties related to mechanical composition of soil, which entail economic consequences may be linked to the need to use agricultural machines of strengthened construction and high-power engines. In the extreme case, heavily rocky land with steep slopes should be assigned for land use change in the first place.

\section{Material and Methods}

The models of potential surface water erosion and agronomic difficulties have been prepared based on the study of slopes illustrating slope classes and soil texture class of surface layer of soil. The study of slopes was prepared based on a digital terrain model prepared with the accuracy of 5 meters. It was generated with the help of krigging method with the use of Gauss function in SAGA GIS software. Source data was obtained from two independent sources: SRTM data [http://srtm.usgs.gov] in WGS84 (EPSG:3120) (Eng. Shuttle Radar Topography Mission) for southern Poland and a topographic map scaled 1:10,000 in 1992 layout (EPSG: 2180). Acquiring data from the topographic map included the digitalization of all level points within the area of the commune. The decision was made to digitalize an additional zone due to the possibility of the existence of artefacts withing the boundaries of DTM and included 200 meters beyond the area of the commune. The study of slope gradients was generated based on Geospatial Data Abstraction Library [4] built into QGIS software. The generated map of slopes was reclassified from continuous values into discrete values at fixed decline intervals. This procedure was performed with the help of the r.reclass algorithm used in GRASS software (Geographic Resources Analysis Support System) [http://www.grass.osgeo.org].

The obtained study of slopes was processed with the help of geoprocessing multiplied by a matrix of objects representing: agricultural production area and soil and agricultural map. Soil map was created after calibrating and vectorizing the analog material on a scale of 1:5,000, whilst the map of agricultural production area was a selection of arable land from the map of agricultural land. The object on the resulting layer was, at this stage of the study, the smallest area of homogenous land use conditions, soils and slope gradient. Obtaining the study of cultivation difficulty or water erosion required the use of the command selecting a set of specific parameters and giving value to "rap" parameter according to the formula below, 
represented in Figure 1. The final representation of results is a spatial classification of objects on the results layer based on a gradual scale of cultivation difficulty and water erosion. In both cases, it was decided to apply a transition of colour tone from the green colour gradient (for the lowest degree of difficulty and erosion) to red for the highest. Settlement of the surface of objects in each class and towns or villages was conducted with the help of procedures from the GROUP STAT software package - QGIS environment [21].

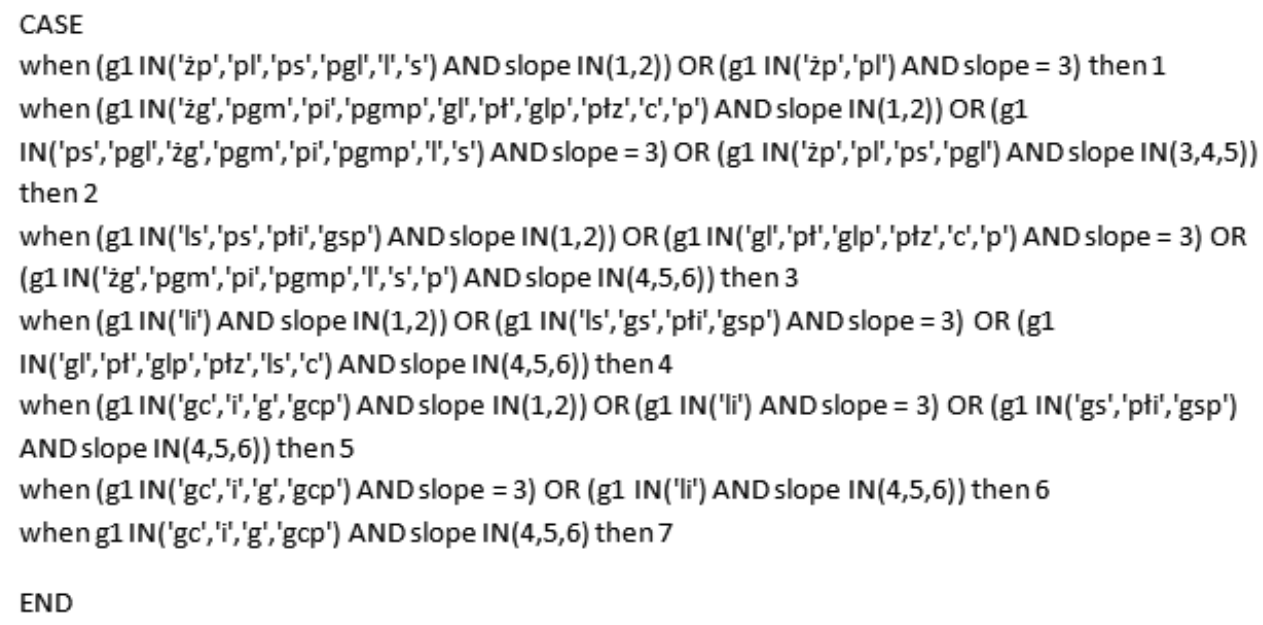

Fig. 1. Query code generating the model of spatial distribution of degrees of cultivation difficulty

\section{Results and Discussion}

Multicriteria analysis of spatial data (Fig. 1) made it possible to develop models of cultivation difficulty and potential risk of surface water erosion. It was also possible to generate spatial objects (Figs 2,3) and tables (Tabs 1, 2).

The analysis was performed for the area of the commune of Tomice, situated in the district of Wadowice in the Małopolska region. Out of the total commune area of $41.5 \mathrm{~km}^{2}$, which consists of 7 villages, slightly more than $66 \%$ of land is designated in the local spatial plan as agricultural production area. The central part of the commune is cut across by the Skawa River, flowing from the south-east to the north-west, which also constitutes a border between the right bank part of the commune, diversified in terms of land relief and its left bank, which mainly includes flat plains. The specific land configuration and the vicinity of the river were the reasons why local soils have developed a very characteristic soil texture class. 
Based on the spatial model of cultivation difficulty in Tomice commune (Fig. 2) it can be seen that a very insignificant percentage of soils in particular villages constitute those of high cultivation difficulty. The area is clearly dominated by soils classified as the third and fourth degree of cultivation difficulty (Tab. 1). Their total area constitutes over $86 \%$ of the analyzed area; $49 \%$ of which includes third degree (moderately easy to cultivate), and slightly more than $37 \%$ are lands which are moderately difficult to cultivate.

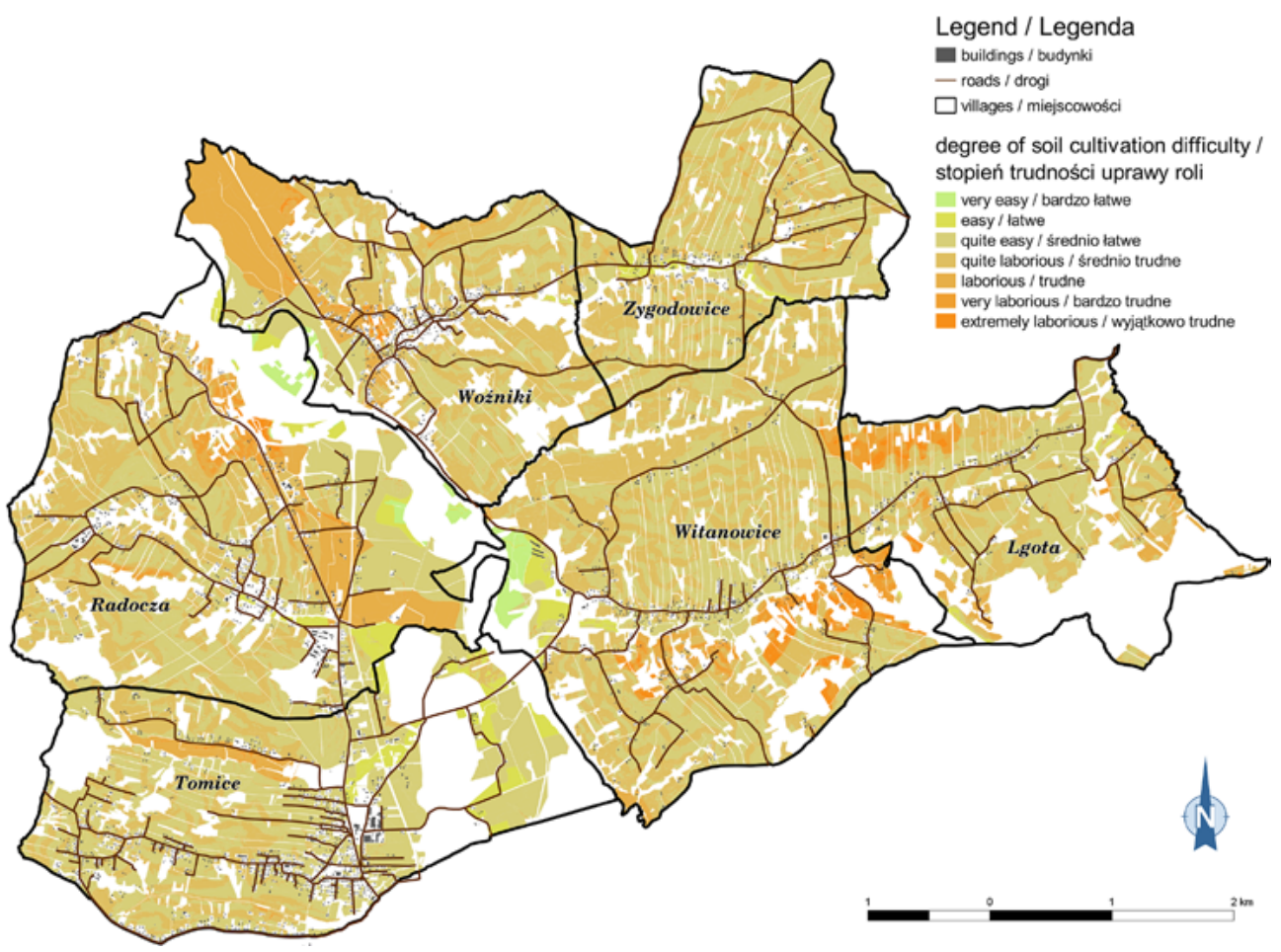

Fig. 2. Soil cultivation difficulty - results for the commune of Tomice

Soils which are difficult to cultivate cover approx. $7 \%$ of the analyzed agricultural production area. In the case of Tomice, it can be noted that slope gradient is one of the key factors influencing the degree of soil cultivation difficulty. To a lesser extent, agronomic difficulties are determined by soil texture class, which in this case was less diversified. The highest percentage of moderately easy soils can be found in Tomice (more than 66\%) and Zygodowice (more than 55\%), whilst the largest surface area of moderately laborious soils is located in Witanowice (almost 50\%). The characteristic areas excluded from the analysis were fish farms located in the valley of the meandering river and small forest complexes in different villages within the commune. Spatial policy of the commune should aim towards designating most difficult soils for non-agricultural purposes. 


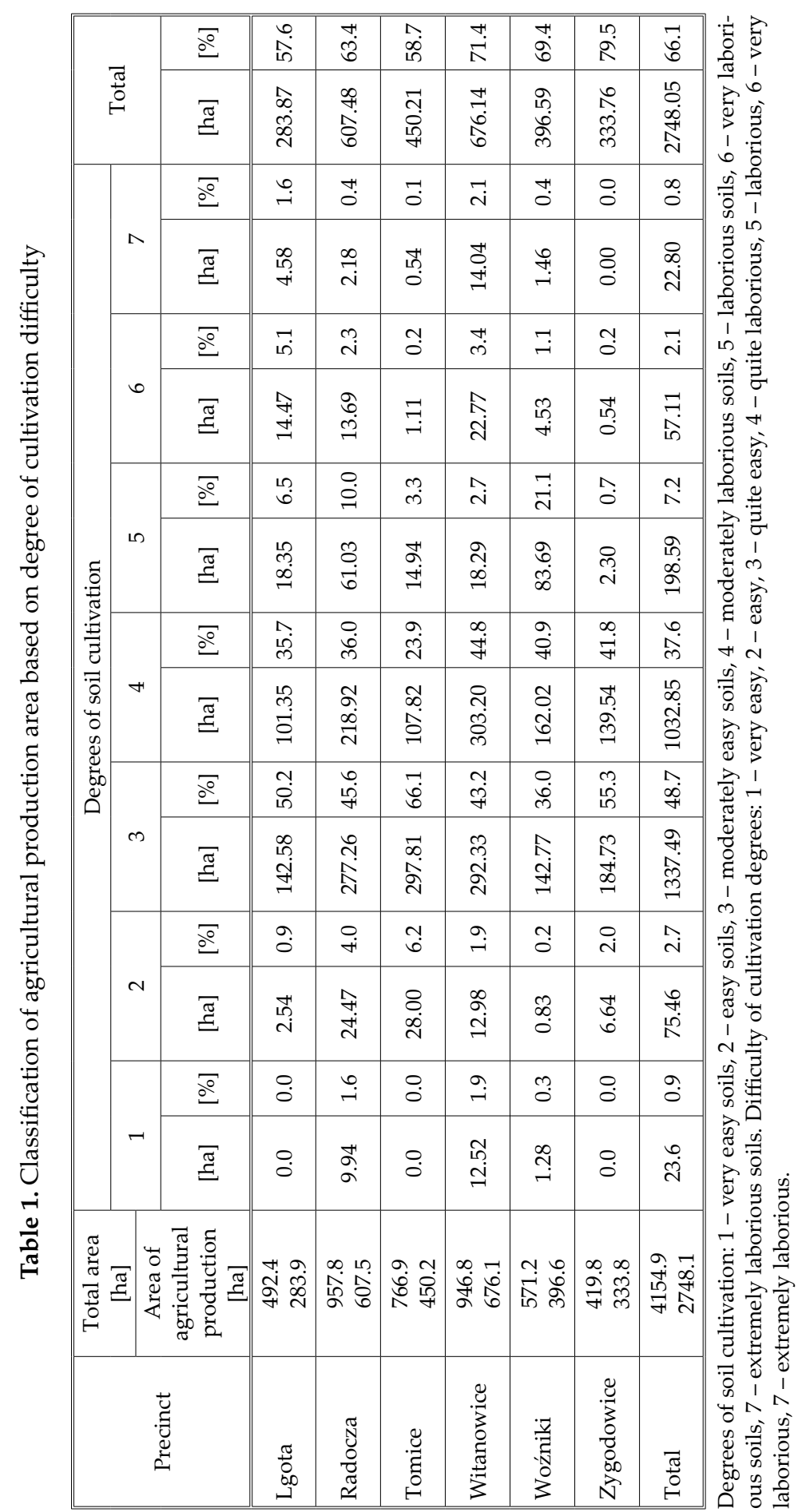




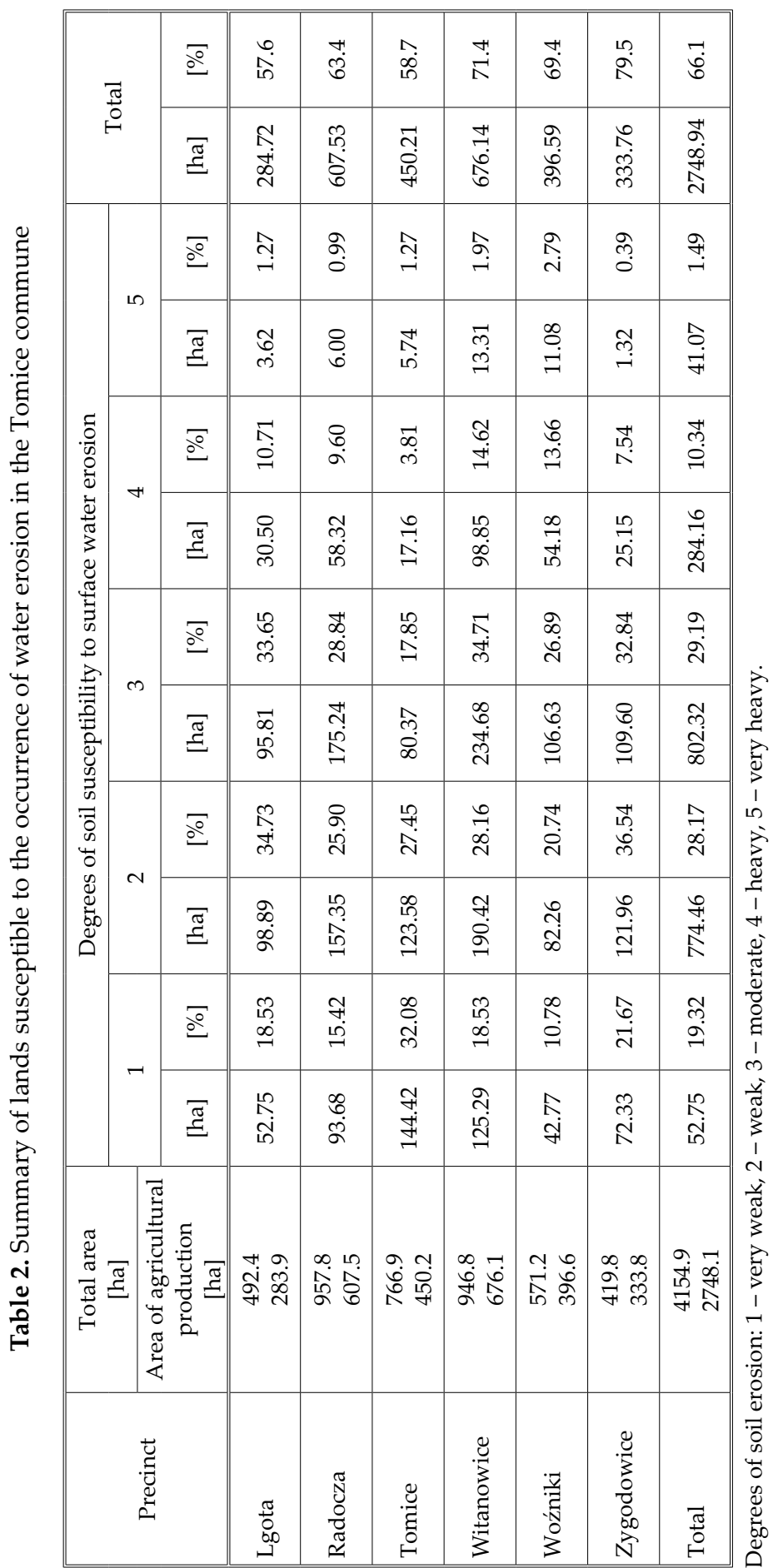


The conducted analysis of potential risk by surface water erosion shows that the degrees of risk differ across the whole commune area (Fig. 3).

An almost two-kilometre wide belt of the Skawa valley, as in the case of agro-technical difficulties, was partly excluded from the analysis and partly outside the area threatened by erosion. $88.5 \%$ of the agricultural production area in Tomice commune is threatened by surface water erosion. Agricultural production areas constitute $58 \%$ of the total commune are (Tab. 2). Almost $12 \%$ of agricultural production area in Tomice (which is $7.8 \%$ of the total area) was classified as land susceptible to erosion at 4 th and 5 th degree. The largest risk areas are located in Witanowice and Woźniki (over $11 \%$ of the total area in each of these villages).

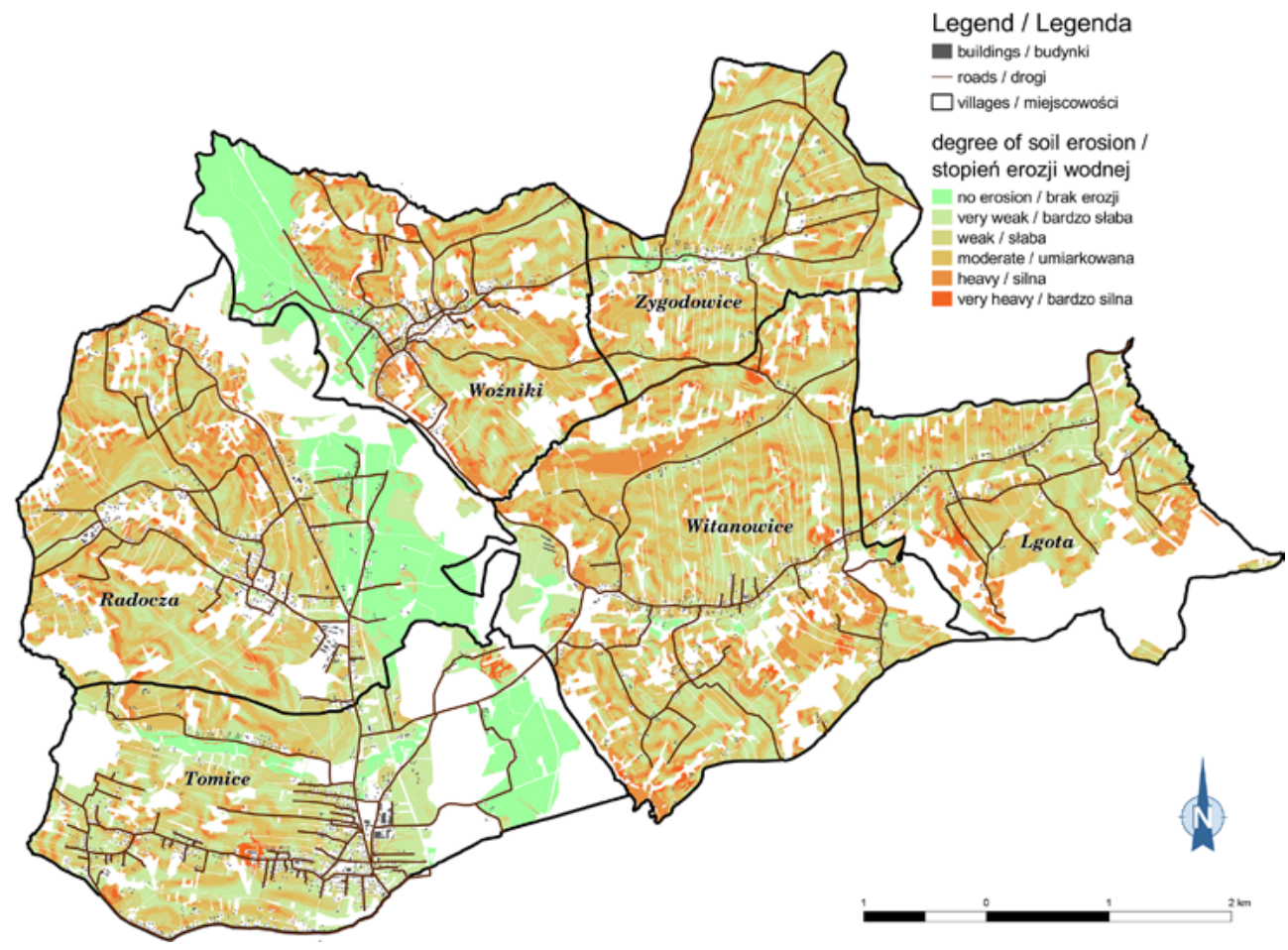

Fig. 3. The spatial model of the potential threat of surface water erosion in Tomice commune

The occurrence of erosion in these degrees of severity is very unfavourable for the agricultural production area because of possible adverse effects, including the need for total exclusion of land from production and designating it for anti-erosion treatments or change of land use. The highest risk of surface water erosion can be registered in villages with variable relief configuration. As in the case of agronomic difficulties, the risk of erosion mainly depends on land relief. 


\section{Conclusions}

The analysis of agricultural production area in the form of a model of cultivation difficulty and potential surface water erosion risks with the help of GIS tools makes it possible to define problem areas in a very accurate way. The presented impairment is related to the mechanical cultivation of land which constitutes the resources of agricultural production area. The conducted analysis can be a starting point for the development of effective erosion control programmes. It can be also helpful in making decision about the future allocation of land for specific purposes. Having assessed the conducted analysis, it can be concluded that the important element of the model is the classification of soils in terms of susceptibility to flushing. In the case of agronomic difficulties, another important factor is the textural group in the arable layer of soil; however, the classification refers to the degree if soil gravity. Heavy soils (heavy clay, loam) are less susceptible to washing or erosion. Quite a different observation can be made in the case of loess soils - very susceptible to flushing. They are posed as an example of soils which are most susceptible to erosion; when it comes to agronomic difficulties, they have been classified in the fifth (common loess) and seventh (clayey loess) class of gravity, out of eight. Yet, in the case of area under research, hipsometric conditions were of key importance when in comes to cultivation difficulty and degrees of erosion risk. A specific area in both studies was located in the valley of the Skawa River. In physiographic terms, the flat valley differs significantly from the surrounding areas. In the case of the studied area, the largest percentage of agricultural production area is characterized by fourth and fifth degree of difficulty of cultivation (moderately easy soils and moderately laborious soils), and also second and third degree of surface water erosion risk (weak and moderate erosion).

\section{References}

[1] Baryła A., Pierzgalski E., Jodłowski P.: Określenie strat gleby wskutek erozji wodnej. Inżynieria Ekologiczna, no. 18, 2007, pp. 63-65.

[2] Białousz S.: Soil physical degradation: assessment with the use of remote sensing and GIS. [in:] Gliski J., Horabik J., Lipiec J. (eds), Encyclopedia of Agrophysics, Springer, 2011, pp. 761-769.

[3] Filipiak K., Jadczyszyn J.: Kryteria wyboru i ocena obszarów problemowych rolnictwa w Polsce. Studia i Raporty IUNG-PIB, z. 12, 2008, pp. 103-111.

[4] Free and Open Source Software for Geospatial. GDAL - Geospatial Data Abstraction Library, [on-line:] http://www.gdal.org [access: 2014 February].

[5] Gliński P., Przesmycki J.: Wpływ erozji wodnej na krajobraz. Teka Komisji Architektury, Urbanistyki i Studiów Krajobrazowych Oddziału PAN w Lublinie, 2011, pp. 99-107. 
[6] Gotlib D., Iwaniak A., Olszewski R.: GIS. Obszary zastosowań. Wyd. PWN, Warszawa 2007.

[7] Helis M., Górecki A.: Projektowanie zmian użytkowania z uwzględnieniem potencjalnej erozji wodnej gleb i retencji krajobrazu na przykładzie mikrozlewni górskiej. Inżynieria Ekologiczna, nr 32, 2013, pp. 48-54.

[8] Hopfer A., Urban M.: Geodezyjne urządzanie terenów rolnych. PWN, Wraszawa 1984.

[9] Instrukcja nr 3 Ministra Rolnictwa oraz Ministra Leśnictwa i Przemystu Drzewnego z dn. 18 sierpnia 1973 r. w sprawie zasad inwentaryzacji gruntów zagrożonych erozja. Dz.U. $1973 \mathrm{nr}$, poz. 43.

[10] Jadczyszyn J.: Ocena warunków przyrodniczo-ekonomicznych na obszarach zagrożonych erozja wodna w Polsce. Studia i Raporty IUNG-PIB, z. 12, 2008, pp. 155-164.

[11] Jadczyszyn J., Filipiak K., Stuczyński T.: Ocena przestrzennego rozmieszczenia gleb podlegajacych skrajnej marginalizacji na obszarach ONW w Polsce. Studia i Raporty IUNG-PIB, z. 12, 2008, pp. 191-201.

[12] Józefaciuk A., Józefaciuk Cz.: Erozja agroekosystemów. Series: Biblioteka Monitoringu Środowiska, Państwowy Inspektorat Ochrony Środowiska, Warszawa 1995.

[13] Józefaciuk Cz., Józefaciuk A.: Mechanizm i wskazówki metodyczne badania procesów erozji. Series: Biblioteka Monitoringu Środowiska, Państwowy Inspektorat Ochrony Środowiska, Warszawa 1996.

[14] Koreleski K., Gawroński K., Magiera-Braś G.: Ochrona i kształtowania środowiska. Wyd. AR w Krakowie, Kraków 1998.

[15] Koreleski K.: Teoretyczne i praktyczne aspekty systematyki procesów erozji wodnej gleb. Przegląd Naukowy Inżynieria i Kształtowania Środowiska, z. 2(40), 2008, pp. 5-11.

[16] Leszczyńska M.: System wspomagania decyzji optymalizujących rozwój marginalnych obszarów wiejskich. Acta Scientiarum Polonorum. Geodesia et Descriptio Terrarum, vol. 9, nr 4, 2010, pp. 37-48.

[17] Magiera-Braś G.: Warunki przyrodnicze wybranych wsi górskich woj. krakowskiego oraz potrzeby w zakresie prac ulepszajacych przestrzeń rolnicza. ZN AR w Krakowie. Geodezja, z. 13, nr 264, 1992.

[18] Niemiec M., Jóźków G., Borkowski A.: Monitorowanie zmian kształtowania powierzchni terenu spowodowanych erozja wodna z wykorzystaniem naziemnego stanowiska laserowego. Archiwum Fotogrametrii, Kartografii i Teledetekcji, vol. 20, 2009, pp. 333-342.

[19] OSGeo Foundation, GRASS (Geographic Resources Analysis Support System). [on-line:] http://www.grass.osgeo.org [access: 2014 February].

[20] Prus B., Salata T.: Analiza zasobów rolniczej przestrzeni produkcyjnej w polityce przestrzennej gminy Tomice. Infrastruktura i Ekologia Terenów Wiejskich, 3/II, 2013, pp. 145-157. 
[21] Quantum GIS (QGIS) Plugin Repository. [on-line:] http://plugins.qgis.org/plugins/GroupStats/ [access: 2014 February].

[22] Salata T., Prus B.: Delimitacja obszarów na potrzeby planowania przestrzennego. Acta Scientiarum Polonorum. Administratio Locorum, vol. 11, nr 3, 2012, pp. 215-225.

[23] United States Geological Survey. [on-line:] http://srtm.usgs.gov [access: 2014 February].

[24] Ustawa z dnia 3 lutego 1995 r. o ochronie gruntów rolnych i leśnych. Dz.U. 2004 nr 121, poz. 1266.

[25] Witek T., Górski T.: Przyrodnicza bonitacja rolniczej przestrzeni produkcyjnej w Polsce. Wydawnictwa Geologiczne, Warszawa 1977.

[26] Witek T. (red.): Waloryzacja rolniczej przestrzeni produkcyjnej Polski wedtug gmin. Instytut Uprawy, Nawożenia i Gleboznawstwa, Puławy 1981.

[27] Zaliwski A., Stuczyński T., Jadczyszyn J., Bielecka E., Fedorowicz-Jackowski W.: Dla użytkowników czy na pótkę? GIS projekt. Zintegrowany system informacji o rolniczej przestrzeni produkcyjnej Polski. Geodeta, nr 10(65), 2000, pp. 35-39. 